\title{
Oxadiazole-Functionalized fibers for selective adsorption of
}

\section{$\mathrm{Hg}^{2+}$}

Huimin Dua ${ }^{\mathrm{a}}$ Yujia Xie ${ }^{\mathrm{a}}$, Haonan Zhang ${ }^{\mathrm{a}}$, Anyaegbu Chima ${ }^{\mathrm{a}}$, Minli Tao*a, and

Wenqin Zhang*a,c

${ }^{a}$ Department of Chemistry, School of Sciences, Tianjin University, Tianjin, 300072, P. R. P. R. China.

b National Demonstration Center for Experimental Chemistry \& Chemical Engineering Education, Tianjin University, Tianjin 300350, China.

${ }^{\mathrm{c}}$ Collaborative Innovation Center of Chemical Science and Engineering (Tianjin), Tianjin 300072, P. R. China.

* Corresponding author. mltao@tju.edu.cn, wqzhang@tju.edu.cn 


\section{Table of Contents}

1. Reagents

2. Apparatus and Instruments

3. Preparation of 1,3,4-Oxadiazole Derivatives

4. Optimization of Synthetic Conditions for 1,3,4-Oxadiazole Derivatives

5. Structural Characterizations of the Fibers

6. Adsorption Dynamics

7. Adsorption Isotherms

8. Comparison of Selective Adsorption Capacities

9. ${ }^{1} \mathrm{H}$ NMR Spectra 


\section{Reagents}

Commercially available polyacrylonitrile fiber (PANF, consisting of 93.0\% acrylonitrile, $6.5 \%$ methyl acrylate and $0.4-0.5 \%$ sodium styrene sulfonate) was cut into lengths of about $8 \mathrm{~cm}$ before use (from the Fushun Petrochemical Corporation of

China). 1,3-propanediamine, formaldehyde, nitric acid, 2,4-dihydroxybenzoic acid, Methyl salicylate, Hydrazine (80\%), $\mathrm{CS}_{2}$, 2-iodopyridine, 2-chloromethylpyridine, 2-(2-hydroxyethyl)pyridine, 1,10-phenanthroline, Ammonium thiocyanate, CuI, KI, $\mathrm{KOH}, \mathrm{NaOH}, \mathrm{K}_{2} \mathrm{CO}_{3}, \mathrm{Na}_{2} \mathrm{CO}_{3}, \mathrm{DMF}$, EDTA, $\mathrm{H}_{2} \mathrm{SO}_{4}, \mathrm{HCl}$, DMSO, Acetone. Heavy metal ion salt (mercury salt select $\mathrm{Hg}\left(\mathrm{ClO}_{4}\right)_{2} \cdot 3 \mathrm{H}_{2} \mathrm{O}$ ) and the other reagents are all analytical grade and used without further purification. The water is deionized.

\section{Apparatus and Instruments}

AVATAR 360 Fourier Transform Infrared Spectrometer (Thermo Nicolet) was used to record infrared spectral data (FT-IR); a S-4800 scanning electron microscope(SEM) from Hitachi was used to determine all fibers; Vario Elemental analyzer (EA) from Elementar was used to measure the elemental analysis data; the $\mathrm{pH}$ value of the solution was adjusted using a PHS-3C pH meter; the hydrogen spectrum $\left({ }^{1} \mathrm{H}\right.$ NMR $)$ of the compound was recorded using an AVANCE III nuclear magnetic resonance instrument (Bruker, $400 \mathrm{MHz}$ ), with TMS as Internal standard; X-ray powder diffraction data (XRD) was performed on a D/MAX-2500-ray powder diffractometer (Rigaku Corporation); IRIS Advantage ICP-9000 Atomic Emission Analyzer (Thermo) was used to measure the heavy metal ion concentration; PHS-25 type $\mathrm{pH}$ meter 
(Shanghai Lei magnetic) was used to test the $\mathrm{pH}$ value of the solution; NexION 300D ICP-MS (PerkinElmer) was used to measure the content for low-concentration heavy metal ions.

\section{Preparation of 1,3,4-Oxadiazole Derivatives}

The overall synthesis route is as follows:<smiles>[R]c1ccc(C(=O)O)c(O)c1</smiles>

1

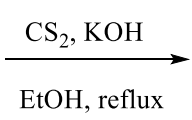

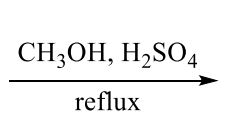<smiles>[R]c1ccc(C(=O)OC)c(O)c1</smiles>

2<smiles>[R]c1ccc(C(=O)NN)c(O)c1</smiles>

3

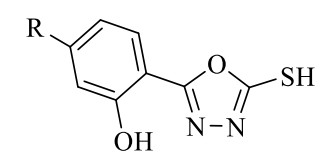

4 $\mathrm{MOP}(\mathrm{R}=\mathrm{H})$ $\operatorname{MOBD}(\mathrm{R}=\mathrm{OH})$

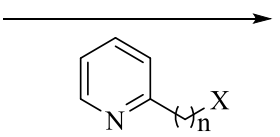

$(\mathrm{X}=\mathrm{I}, \mathrm{n}=0 ; \mathrm{X}=\mathrm{Cl}, \mathrm{n}=1$ or 2$)$<smiles>[R]c1ccc(-c2nnc(S[GaH]c3ccccn3)o2)c(O)c1</smiles>

5

PTOP $(\mathrm{R}=\mathrm{H}, \mathrm{n}=0)$ $\operatorname{PMOP}(\mathrm{R}=\mathrm{H}, \mathrm{n}=1)$ PEOP $(\mathrm{R}=\mathrm{H}, \mathrm{n}=2)$ PMOD $(\mathrm{R}=\mathrm{OH}, \mathrm{n}=1)$

\subsection{Synthesis of Methyl 2,4-Dihydroxybenzoate}<smiles>O=C(O)c1ccc(O)cc1O</smiles>

$1 \mathrm{~b}$

$$
\underset{\text { reflux }}{\stackrel{\mathrm{CH}_{3} \mathrm{OH}, \mathrm{H}_{2} \mathrm{SO}_{4}}{\longrightarrow}}
$$

$2 b$

2,4-dihydroxybenzoic acid (6.16 g, $40.0 \mathrm{mmol})$ and methanol $(100 \mathrm{~mL})$ were added to a $250 \mathrm{~mL}$ three-necked flask. Concentrated sulfuric acid $(10 \mathrm{~mL})$ was slowly added dropwise to the above mixed system under constant stirring, and refluxed for 8 hours. After cooling to room temperature, the methanol was removed under reduced pressure. 
The reaction solution was adjusts to neutral by $\mathrm{K}_{2} \mathrm{CO}_{3}$ (aq.), extracted with ethyl acetate $(3 \times 30 \mathrm{~mL})$, dried by $\mathrm{MgSO}_{4}$, filtered and then ethyl acetate was removed under reduced pressure to give methyl 2,4-dihydroxybenzoate as white solid. $\mathrm{Y}=88 \%$, m.p. $=125{ }^{\circ} \mathrm{C}\left(\right.$ Literature value $\left.^{1}: 118-121{ }^{\circ} \mathrm{C}\right) .{ }^{1} \mathrm{H}$ NMR $\left(400 \mathrm{MHz}, \mathrm{CDCl}_{3}\right) \delta 11.01(\mathrm{~s}$, 1H), $7.75(\mathrm{~d}, \mathrm{~J}=6.0 \mathrm{~Hz}, 1 \mathrm{H}), 6.43-6.38(\mathrm{~m}, 2 \mathrm{H}), 3.94(\mathrm{~s}, 3 \mathrm{H})$.

\subsection{Synthesis of Hydroxybenzoyl Hydrazide}<smiles>[R]c1ccc(C(=O)OC)c(O)c1</smiles>

2

$$
\underset{\mathrm{CH}_{3} \mathrm{OH}, \text { reflux }}{\stackrel{\mathrm{NH}_{2} \mathrm{NH}_{2} \cdot \mathrm{H}_{2} \mathrm{O}}{\longrightarrow}}
$$<smiles>[R]c1ccc(C(=O)NN)c(O)c1</smiles>

3a, $\mathrm{R}=\mathrm{H}$ $3 \mathrm{~b}, \mathrm{R}=\mathrm{OH}$

2 (40.0 mmol), 80\% hydrazine hydrate $(30 \mathrm{~mL})$ and methanol $(100 \mathrm{~mL})$ were added to a $250 \mathrm{~mL}$ three-necked flask, and refluxed for $6 \mathrm{~h}$. After cooling to room temperature, methanol was removed under reduced pressure, and distilled water was added until the white product is sufficiently precipitated. Then it was filtered and washed with water to give substituted hydroxybenzoyl hydrazide $\mathbf{3}$ as white needle crystals. 3a:Y=91\%, m.p. $=149-151{ }^{\circ} \mathrm{C},{ }^{1} \mathrm{H}$ NMR (400 MHz, DMSO-d6) $\delta 12.48$ (s, 1H), $10.05(\mathrm{~s}, 1 \mathrm{H}), 7.80(\mathrm{~d}, \mathrm{~J}=6.0 \mathrm{~Hz}, 1 \mathrm{H}), 7.38(\mathrm{t}, \mathrm{J}=6.0 \mathrm{~Hz}, 1 \mathrm{H}), 6.91-6.86(\mathrm{~m}$, 2H), $4.66(\mathrm{~s}, 1 \mathrm{H})$. (Basically consistent with the reported data in the literat ure ${ }^{2}$ ). $3 \mathbf{b}: \mathrm{Y}$ $=84 \%$, m.p. $=226-235{ }^{\circ} \mathrm{C},{ }^{1} \mathrm{H}$ NMR $(400 \mathrm{MHz}, \mathrm{DMSO}-\mathrm{d} 6) \delta 7.62(\mathrm{~d}, \mathrm{~J}=9.0 \mathrm{~Hz}, 1 \mathrm{H})$, $6.23(\mathrm{t}, \mathrm{J}=3.0 \mathrm{~Hz}, 2 \mathrm{H}), 3.99(\mathrm{~s}, 2 \mathrm{H})$. (Basically consistent with the reported data in the literature $\left.{ }^{3}\right)$.

\subsection{Synthesis of Phenyloxadiazole}


<smiles>[R]c1ccc(C(=O)NN)c(O)c1</smiles>

3

$$
\underset{\text { EtOH, reflux }}{\stackrel{\mathrm{CS}_{2}, \mathrm{KOH}}{\longrightarrow}}
$$<smiles>[R]c1ccc(-c2nnc(S)o2)c(O)c1</smiles>

4a: $\mathrm{MOP}, \mathrm{R}=\mathrm{H}$ 4b: $\mathrm{MOD}, \mathrm{R}=\mathrm{OH}$

3 (40.0 mmol), $\mathrm{KOH}(2.24 \mathrm{~g}, 40.0 \mathrm{mmol})$ and ethanol $(100 \mathrm{~mL})$ were added to a 250 $\mathrm{mL}$ three-necked flask. $\mathrm{CS}_{2}(3.0 \mathrm{~mL}, 48.0 \mathrm{mmol})$ was slowly added dropwise to the above mixed system under constant stirring, and refluxed for 8 hours. After cooling to room temperature, ethanol was concentrated to remove, and the obtained white solid was dissolved in distilled water $(30 \mathrm{~mL})$. The solution was adjusts to $\mathrm{pH}=4-5$ by $\mathrm{HCl}$ (aq.), filtered and then the solid was washed with water, recrystallized from ethanol to get white solid. 4a: Y $=82 \%$, m.p. $=196{ }^{\circ} \mathrm{C},{ }^{1} \mathrm{H}$ NMR $(400 \mathrm{MHz}, \mathrm{DMSO}-\mathrm{d} 6) \delta 14.65$ $(\mathrm{s}, 1 \mathrm{H}), 10.47(\mathrm{~s}, 1 \mathrm{H}), 7.65(\mathrm{~d}, \mathrm{~J}=3.0 \mathrm{~Hz}, 1 \mathrm{H}), 7.43(\mathrm{t}, \mathrm{J}=6.0 \mathrm{~Hz}, 1 \mathrm{H}), 7.05(\mathrm{~d}, \mathrm{~J}=$ $6.0 \mathrm{~Hz}, 1 \mathrm{H}), 6.96(\mathrm{t}, \mathrm{J}=6.0 \mathrm{~Hz}, 1 \mathrm{H})$. (Basically consistent with the reported data in the literature $\left.{ }^{4}\right) . \mathbf{4 b}: \mathrm{Y}=80 \%$, m.p. $=236-243{ }^{\circ} \mathrm{C},{ }^{1} \mathrm{H}$ NMR $(400 \mathrm{MHz}, \mathrm{DMSO}-\mathrm{d} 6) \delta$ $14.06(\mathrm{~s}, 1 \mathrm{H}), 10.27(\mathrm{~s}, 1 \mathrm{H}), 10.17(\mathrm{~s}, 1 \mathrm{H}), 7.47(\mathrm{~d}, \mathrm{~J}=9.0 \mathrm{~Hz}, 1 \mathrm{H}), 6.46(\mathrm{~s}, 1 \mathrm{H}), 6.38$ $(\mathrm{d}, \mathrm{J}=3.0 \mathrm{~Hz}, 1 \mathrm{H})$.

\subsection{Synthesis of Oxadiazole Derivatives Containing Py ridyl and Hydroxyphenyl}

\section{Groups}

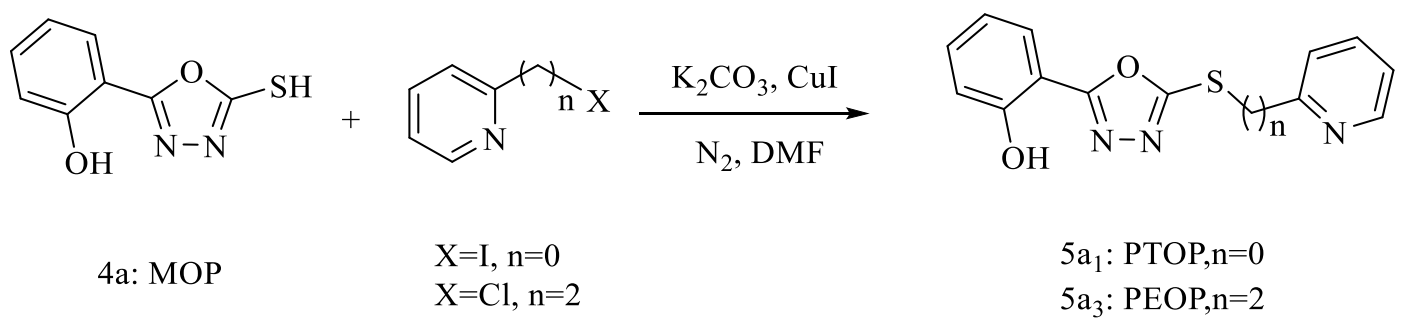

2-(2-hydroxyethyl)pyridine $(30.0 \mathrm{~g}, 0.24 \mathrm{~mol})$ was added to a $50 \mathrm{~mL}$ three-necked flask under nitrogen atmosphere, placed in an ice water bath. Dichlorosulfoxide (35.0 $\mathrm{mL}, 0.48 \mathrm{~mol})$ dissolved in dichloromethane $(35.0 \mathrm{~mL})$ was slowly added dropwise to 
the above solution, and reacted at room temperature for $2 \mathrm{~h}$. Dichloromethane and dichlorosulfoxide were removed under reduced pressure, added to distilled water (30.0 mL). The mixture was adjusts to $\mathrm{pH}=4$ by $\mathrm{HCl}$ (aq.), extracted with dichloromethane $(3 \times 30 \mathrm{~mL})$, and then ethyl acetate was removed under reduced pressure to give 2-(2-chloroethyl)pyridine for using.

$\mathrm{K}_{2} \mathrm{CO}_{3}$ (0.45 g, $\left.3.25 \mathrm{mmol}\right), \mathrm{CuI}(0.024 \mathrm{~g}, 0.125 \mathrm{mmol})$, substituted pyridine (3.0 mmol) and DMF (6.5 mL) were added to a $100 \mathrm{~mL}$ three-necked flask under nitrogen atmosphere, and stirred at room temperature for 1 h. $4 \mathbf{a}(9.3 \mathrm{~g}, 48.0 \mathrm{mmol})$ dissolved in DMF (6.5 mL) was slowly added dropwise to the above mixed system, and reacted at $100{ }^{\circ} \mathrm{C}$ for $10 \mathrm{~h}$. After cooling to room temperature, organic layer was washed with distilled water $(30 \mathrm{~mL})$, extracted with ethyl acetate $(3 \times 30 \mathrm{~mL})$, dried by $\mathrm{MgSO}_{4}$, filtered and ethyl acetate was removed under reduced pressure, then purified by column chromatograph (silica gel, PE/EA = 20:1, Volume ratio), affording production

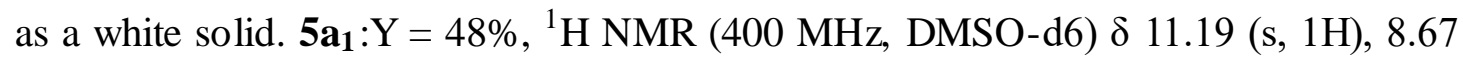
$(\mathrm{d}, \mathrm{J}=3.0 \mathrm{~Hz}, 1 \mathrm{H}), 8.11(\mathrm{t}, \mathrm{J}=6.0 \mathrm{~Hz}, 1 \mathrm{H}), 8.00(\mathrm{~d}, \mathrm{~J}=3.0 \mathrm{~Hz}, 1 \mathrm{H}), 7.89(\mathrm{~d}, \mathrm{~J}=6.0$ $\mathrm{Hz}, 1 \mathrm{H}), 7.55(\mathrm{t}, \mathrm{J}=6.0 \mathrm{~Hz}, 1 \mathrm{H}), 7.45(\mathrm{t}, \mathrm{J}=6.0 \mathrm{~Hz}, 1 \mathrm{H}), 7.10-7.02(\mathrm{~m}, 2 \mathrm{H})$. 5a $3: Y=78 \%,{ }^{1} \mathrm{H}$ NMR (400 MHz, DMSO-d6) $\delta 10.51(\mathrm{~s}, 1 \mathrm{H}), 8.51(\mathrm{~d}, \mathrm{~J}=3.0 \mathrm{~Hz}, 1 \mathrm{H})$, $7.72(\mathrm{t}, \mathrm{J}=6.0 \mathrm{~Hz}, 1 \mathrm{H}), 7.62(\mathrm{~d}, \mathrm{~J}=6.0 \mathrm{~Hz}, 1 \mathrm{H}), 7.44(\mathrm{t}, \mathrm{J}=6.0 \mathrm{~Hz}, 1 \mathrm{H}), 7.34(\mathrm{~d}, \mathrm{~J}=$ $6.0 \mathrm{~Hz}, 1 \mathrm{H}), 7.26(\mathrm{t}, \mathrm{J}=6.0 \mathrm{~Hz}, 1 \mathrm{H}), 7.06(\mathrm{~d}, \mathrm{~J}=6.0 \mathrm{~Hz}, 1 \mathrm{H}), 6.97(\mathrm{t}, \mathrm{J}=6.0 \mathrm{~Hz}, 1 \mathrm{H})$, $4.47(\mathrm{t}, \mathrm{J}=6.0 \mathrm{~Hz}, 2 \mathrm{H}), 3.28(\mathrm{t}, \mathrm{J}=6.0 \mathrm{~Hz}, 2 \mathrm{H})$. 
<smiles>[R]c1ccc(-c2nnc(S)o2)c(O)c1</smiles>

4

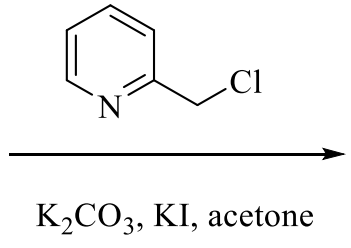

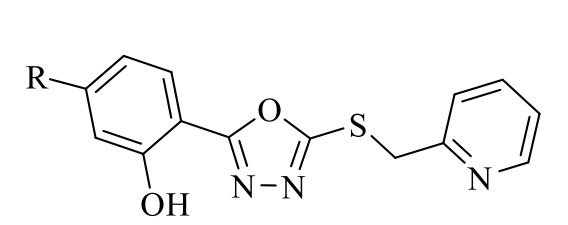

$5 \mathrm{a}_{2}$ : PMOP, $\mathrm{R}=\mathrm{H}$

5b: PMOD, $\mathrm{R}=\mathrm{OH}$

2-chloromethylpyridine hydrochloride $(8.5 \mathrm{~g}, 52.0 \mathrm{mmol}), \mathrm{Na}_{2} \mathrm{CO}_{3}(5.51 \mathrm{~g}, 52.0$ mmol), distilled water $(30.0 \mathrm{~mL})$ were added to a $100 \mathrm{~mL}$ flask, extracted with ethyl acetate $(3 \times 30 \mathrm{~mL})$. Ethyl acetate was removed under reduced pressure to give 2-chloromethylpyridine.

4 (50.0 mmol), $\mathrm{K}_{2} \mathrm{CO}_{3}(9.0 \mathrm{~g}, 65.0 \mathrm{mmol}), \mathrm{KI}(0.042 \mathrm{~g}, 0.25 \mathrm{mmol})$ and acetone (15.0 $\mathrm{mL}$ ) were added to a $100 \mathrm{~mL}$ three-necked flask and allowed to react at room temperature for $1 \mathrm{~h}$. 2-chloromethylpyridine $(8.5 \mathrm{~g}, 52.0 \mathrm{mmol})$ dissolved in acetone $(10.0 \mathrm{~mL})$ was added dropwise to the above mixture and refluxed for $4 \mathrm{~h}$. After cooling to room temperature, the acetone was removed under reduced pressure.

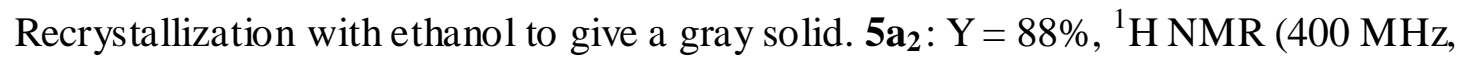
$\left.\mathrm{CDCl}_{3}\right) \delta 9.86(\mathrm{~s}, 1 \mathrm{H}), 8.64(\mathrm{~d}, \mathrm{~J}=3.0 \mathrm{~Hz}, 1 \mathrm{H}), 7.81(\mathrm{t}, \mathrm{J}=6.0 \mathrm{~Hz}, 1 \mathrm{H}), 7.70(\mathrm{~d}, \mathrm{~J}=$ $6.0 \mathrm{~Hz}, 1 \mathrm{H}), 7.65(\mathrm{~d}, \mathrm{~J}=6.0 \mathrm{~Hz}, 1 \mathrm{H}), 7.45(\mathrm{t}, \mathrm{J}=6.0 \mathrm{~Hz}, 1 \mathrm{H}), 7.35(\mathrm{t}, \mathrm{J}=6.0 \mathrm{~Hz}, 1 \mathrm{H})$, $7.13(\mathrm{~d}, \mathrm{~J}=6.0 \mathrm{~Hz}, 1 \mathrm{H}), 7.01(\mathrm{t}, \mathrm{J}=6.0 \mathrm{~Hz}, 1 \mathrm{H}), 4.75(\mathrm{~s}, 2 \mathrm{H}) .5 \mathbf{b}: \mathrm{Y}=84 \%,{ }^{1} \mathrm{H} \mathrm{NMR}$ $(400 \mathrm{MHz}, \mathrm{DMSO}-\mathrm{d} 6) \delta 8.53(\mathrm{~d}, \mathrm{~J}=3.0 \mathrm{~Hz}, 1 \mathrm{H}), 7.78(\mathrm{t}, \mathrm{J}=6.0 \mathrm{~Hz}, 1 \mathrm{H}), 7.53(\mathrm{~d}, \mathrm{~J}=$ $6.0 \mathrm{~Hz}, 1 \mathrm{H}), 7.32-7.29(\mathrm{~m}, 1 \mathrm{H}), 7.11(\mathrm{~d}, \mathrm{~J}=6.0 \mathrm{~Hz}, 1 \mathrm{H}), 5.72(\mathrm{~d}, \mathrm{~J}=6.0 \mathrm{~Hz}, 1 \mathrm{H})$, $5.68(\mathrm{~d}, \mathrm{~J}=6.0 \mathrm{~Hz}, 1 \mathrm{H}), 4.57(\mathrm{~s}, 2 \mathrm{H})$.

\section{Optimization of Synthetic Conditions for 1,3,4-Oxadiazole Derivatives}


The first three steps for the synthesis of 1,3,4-oxadiazole derivatives are very mature with high yields, and the post-processing operations are simple and easy to control. In the final step, the choice of reaction time, catalyst, solvent and reaction temperature has a great effect on the yield. When synthesizing $\mathbf{5} \mathbf{a}_{2}$ and $\mathbf{5 b}$, the yield can be improved by controlling the reaction time. When the reaction time is less than $4 \mathrm{~h}$, the raw materials cannot be completely reacted and the yield is reduced. However, when the reaction time is more than $4 \mathrm{~h}$, the proportion of by-products will increase, resulting in a decrease of yield, so the reaction is selected for $4 \mathrm{~h}$. In the synthesis of $\mathbf{5 a _ { 1 }}$ and $\mathbf{5} \mathbf{a}_{3}$, since 2-iodopyridine and 2-(2-chloroethyl) pyridine are less active than 2-(1-chloromethyl) pyridine, the reaction is difficult to proceed when using acetone or water as solvent and $\mathrm{KI}$ as catalyst. Finally, the reaction was performed with $\mathrm{CuI}$ as the catalyst and DMF as the solvent. Meantime, the reaction is basically impossible when the temperature is raised from room temperature to $90{ }^{\circ} \mathrm{C}$, unless the temperature was increased to $100{ }^{\circ} \mathrm{C}$. The reaction conditions are shown in Table S1.

Table S1 Optimization of the Synthesis Conditions

\begin{tabular}{ccclcc}
\hline Derivative & Time $/ \mathrm{h}$ & Temperature $/{ }^{\circ} \mathrm{C}$ & Solvent & catalyst & Yield/\% \\
\hline PMOP & 4 & 56 & acetone & KI & 87.6 \\
PMOP & 5 & 56 & acetone & KI & 61.5 \\
\hline PMOD & 4 & 56 & acetone & KI & 84.2 \\
PMOD & 5 & 56 & acetone & KI & 52.7 \\
\hline PTOP & 4 & 56 & acetone & KI & trace \\
PTOP & 4 & 56 & acetone & CuI & trace \\
PTOP & 4 & 100 & DMF & KI & trace \\
PTOP & 4 & 100 & DMF & CuI & 47.8
\end{tabular}




\begin{tabular}{llllll} 
PTOP & 4 & $0-90$ & $\mathrm{DMF}$ & $\mathrm{CuI}$ & trace \\
PTOP & 4 & 100 & $\mathrm{H}_{2} \mathrm{O}$ & $\mathrm{CuI}$ & trace \\
\hline
\end{tabular}

\section{Structural Characterization of the Fibers}

\subsection{Elemental Analysis (EA)}

Table S2 Elemental Analysis of PANF, PAN ${ }_{\mathrm{P}} \mathrm{F}, \mathrm{PAN}_{\mathrm{p}-\mathrm{PMOD}} \mathrm{F}, \mathrm{PAN}_{\mathrm{p}-\mathrm{PMOD}} \mathrm{F}-\mathrm{Hg}, \mathrm{PAN}_{\mathrm{p}-\mathrm{PMOD}} \mathrm{F}-1$ and PAN $_{\text {p-PMOD }} \mathrm{F}-5$

\begin{tabular}{|c|c|c|c|c|c|c|}
\hline Entry & Sample & $\mathrm{C}(\%)$ & $\mathrm{H}(\%)$ & $\mathrm{N}(\%)$ & $\mathrm{S}(\%)$ & Sum $(\%)$ \\
\hline 1 & PANF & 70.69 & 5.94 & 26.11 & 0.00 & 102.74 \\
\hline 2 & $\mathrm{PAN}_{\mathrm{P}} \mathrm{F}$ & 57.68 & 7.25 & 20.00 & 0.00 & 84.93 \\
\hline 3 & $\mathrm{PAN}_{\mathrm{p}-\mathrm{PMOD}} \mathrm{F}$ & 53.40 & 6.99 & 17.55 & 0.39 & 78.33 \\
\hline 4 & $\mathrm{PAN}_{\mathrm{p}-\mathrm{PMOD}} \mathrm{F}-\mathrm{Hg}$ & 50.86 & 6.16 & 17.52 & 0.24 & 74.78 \\
\hline 5 & $\mathrm{PAN}_{\mathrm{p}-\mathrm{PMOD}} \mathrm{F}-1$ & 53.98 & 6.50 & 18.89 & 0.29 & 79.66 \\
\hline 6 & $\mathrm{PAN}_{\mathrm{p}-\mathrm{PMOD}} \mathrm{F}-5$ & 52.65 & 6.49 & 19.37 & 0.27 & 78.78 \\
\hline
\end{tabular}

The elemental analysis data of PANF, PAN $\mathrm{p}, \mathrm{PAN}_{\mathrm{p}-\mathrm{PMOD}} \mathrm{F}, \mathrm{PAN}_{\mathrm{p}-\mathrm{PMOD}} \mathrm{F}-\mathrm{Hg}$,

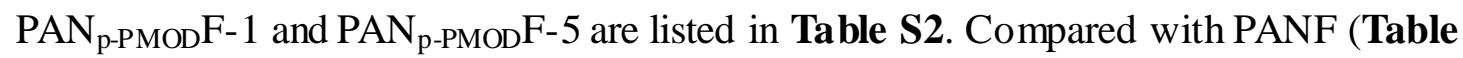
S2, entry 1), the $\mathrm{C}$ and $\mathrm{N}$ content of $\mathrm{PAN}_{\mathrm{p}} \mathrm{F}$ decreased, while the $\mathrm{H}$ content increased significantly (Table S2, entry 2), which is consistent with previous research results of our research group. ${ }^{5}$ It also accords with the fact that the carbon content of propylene diamine molecules $(48.7 \%)$ is smaller than that of PANF $(70.69 \%)$ and the hydrogen content $(13.5 \%)$ is larger than PANF (5.94\%). At the same time, during the amination process, parts of the cyano groups on the PANF were converted to amide to reduce the $\mathrm{N}$ content with the release of $\mathrm{NH}_{3}$, and the total content of these four elements 
decreased due to the introduction of $\mathrm{O}$ element. Compared with $\mathrm{PAN}_{\mathrm{p}} \mathrm{F}$, the $\mathrm{C}$ and $\mathrm{N}$ content of $\mathrm{PAN}_{\mathrm{p}-\mathrm{PMOD}} \mathrm{F}$ decreased after the modification with PMOD, while the $\mathrm{S}$ content increased significantly (Table S2, entry 3). This is because the C (55.8\%) and $\mathrm{N}(13.9 \%)$ content is lower and $\mathrm{S}(10.6 \%)$ content is higher of PMOD than $\mathrm{PAN}_{\mathrm{p}} \mathrm{F}$. This also illustrates the successful grafting of PMOD onto $\mathrm{PAN}_{\mathrm{p}} \mathrm{F}$. In $\mathrm{PAN}_{\mathrm{p}-\mathrm{PMOD}} \mathrm{F}-\mathrm{Hg}$ (Table S2, entry 4), every content of elements decreased, which suggested that $\mathrm{PAN}_{\mathrm{p}-\mathrm{PMOD}} \mathrm{F}$ adsorbs $\mathrm{Hg}^{2+}$ successfully. Comparing the EA data of $\mathrm{PAN}_{\mathrm{p}-\mathrm{PMOD}} \mathrm{F}-1$ (Table S2, entry 5) and PAN $\mathrm{p}_{\mathrm{p}-\mathrm{PMOD}} \mathrm{F}-5$ (Table S2, entry 6) to that of PAN $\mathrm{P}_{\mathrm{p}-\mathrm{PMOD}} \mathrm{F}$, the nitrogen and hydrogen contents increased and the sulfur content decreased which is probably due to the slight degradation of PMOD from $\mathrm{PAN}_{\mathrm{P}} \mathrm{F}$ after being reused. ${ }^{6}$

\subsection{Scanning Electron Microscopy (SEM)}

The SEM images of PANF, PAN $\mathrm{PF}, \mathrm{PAN}_{\mathrm{p}-\mathrm{PMOD}} \mathrm{F}, \mathrm{PAN}_{\mathrm{p}-\mathrm{PMOD}} \mathrm{F}-\mathrm{Hg}, \mathrm{PAN}_{\mathrm{p}-\mathrm{PMOD}} \mathrm{F}-1$ and $\mathrm{PAN}_{\mathrm{p}-\mathrm{PMOD}} \mathrm{F}-5$ are presented in Figure S1. The surface of the original PANF (Figure S1a) has a smooth surface structure. Compared to PANF, the surface of $\mathrm{PAN}_{\mathrm{P}} \mathrm{F}$ (Figure S1b) and PAN $_{\mathrm{p}-\mathrm{PMOD}} \mathrm{F}$ (Figure S1c) become slightly rougher after being modified with propylene diamine and PMOD stepwisely, caused by the swelling of the modifiers after reactions. Compared with $\mathrm{PAN}_{\mathrm{p}-\mathrm{PMOD}} \mathrm{F}$, the surface of the fiber after adsorption of $\mathrm{Hg}^{2+}$ (Figure S1d) did not change significantly. After the fiber was reused for once or five times, the surface of $\mathrm{PAN}_{\mathrm{p}-\mathrm{PMOD}} \mathrm{F}-1$ (Figure S1e) and $\mathrm{PAN}_{\mathrm{p}-\mathrm{PMOD}} \mathrm{F}-5$ (Figure S1f) swell up and become rougher, due to a long period of continuous stirring and the process of desorption of $\mathrm{Hg}^{2+}$ by dilute nitric acid. In short, $\mathrm{PAN}_{\mathrm{p}-\mathrm{PMOD}} \mathrm{F}$ can maintain good structural integrity and adsorption performance after used repeatedly for at least 
5 times.

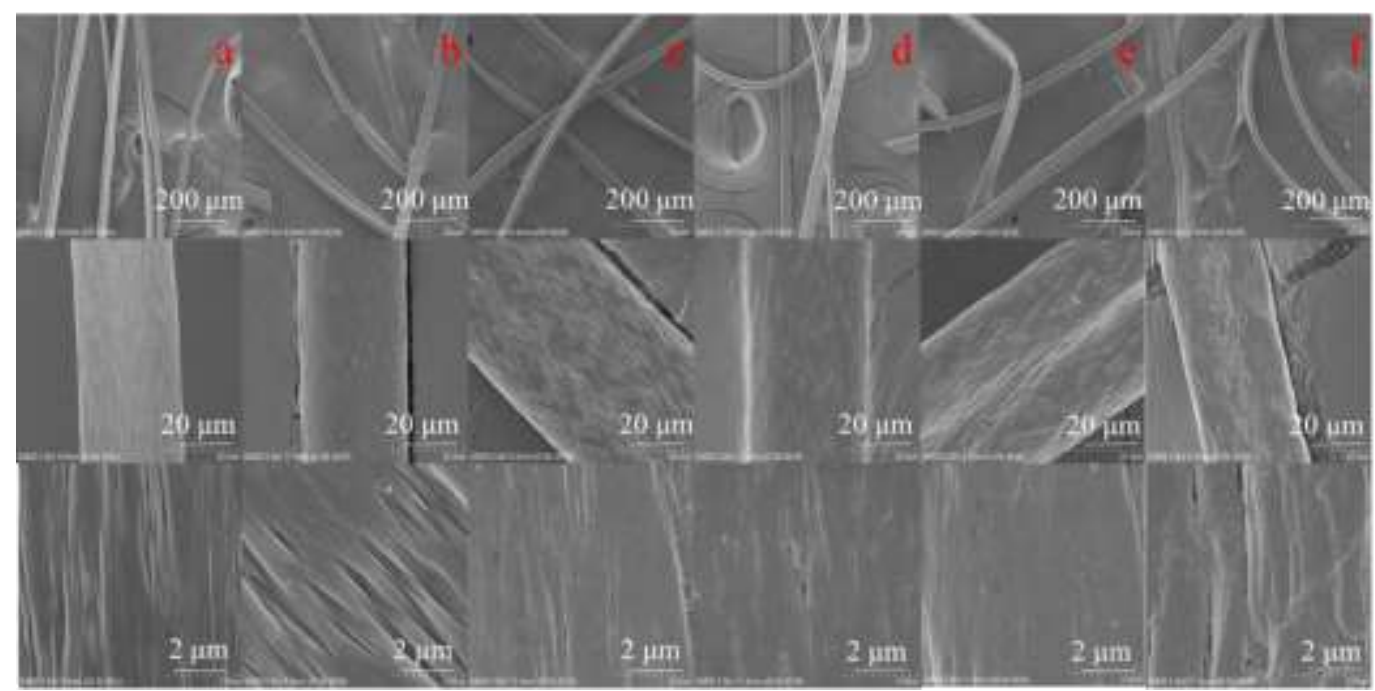

Figure S1 SEM images of (a) PANF, (b) $\mathrm{PAN}_{\mathrm{P}} \mathrm{F}$, (c) $\mathrm{PAN}_{\mathrm{p}-\mathrm{PMOD}} \mathrm{F}$, (d) $\mathrm{PAN}_{\mathrm{p}-\mathrm{PMOD}} \mathrm{F}-\mathrm{Hg}$, (e) $\mathrm{PAN}_{\mathrm{p}-\mathrm{PMOD}} \mathrm{F}-1$ and (f) $\mathrm{PAN}_{\mathrm{p}-\mathrm{PMOD}} \mathrm{F}-5$

\subsection{X-ray Diffraction (XRD)}

The X-ray diffraction patterns of PANF, PAN $\mathrm{P}, \mathrm{PAN}_{\mathrm{p}-\mathrm{PMOD}} \mathrm{F}, \mathrm{PAN}_{\mathrm{p}-\mathrm{PMOD}} \mathrm{F}-\mathrm{Hg}$, $\mathrm{PAN}_{\mathrm{p}-\mathrm{PMOD}} \mathrm{F}-1$ and $\mathrm{PAN}_{\mathrm{p}-\mathrm{PMOD}} \mathrm{F}-5$ are shown in Figure $\mathbf{S 2}$. The XRD spectrum of PANF (Figure S2a) shows a sharp peak at $2 \theta=17^{\circ}$, corresponded to the diffraction of the hexagonal lattice due to the intermolecular repulsion of nitrile dipoles, which indicates that PANF has a stiff rod-like conformation. ${ }^{7}$ The diffraction peak at $2 \theta=$ $17^{\circ} \sim 19^{\circ}$ shows a wider diffuse reflection zone because of the disordered phase in the structure. The XRD spectra of the $\mathrm{PAN}_{\mathrm{P}} \mathrm{F}$ (Figure S2b) is consistent with the original fiber but have a slight decrease in its intensity, which is attributed to a decrease of the polar interaction and the breakage of the outer crystal region. ${ }^{6}$ After immobilization of PMOD (Figure S2c), there was no greater change in the intensity of the peak. Indicating that the inner part and the mechanical properties of the functionalized fiber were not affected further. The peak intensity of the $\mathrm{PAN}_{\mathrm{p}-\mathrm{PMOD}} \mathrm{F}-\mathrm{Hg}$ (Figure S2d) 
decreases due to the presence of $\mathrm{Hg}^{2+}$ on the surface of the fiber, which affects its ordering to some extent. After desorption with dilute nitric acid, the $\mathrm{PAN}_{\mathrm{p}-\mathrm{PMOD}} \mathrm{F}-1$ (Figure S2e) and $\mathrm{PAN}_{\mathrm{p}-\mathrm{PMOD}} \mathrm{F}-5$ (Figure S2f) still showed strong peaks at $17^{\circ}$, also indicating that the inner part and the mechanical properties of the functionalized fiber were not affected and the $\mathrm{Hg}^{2+}$ was successfully desorbed, which is consistent with the results of elemental analysis after recycled for at least five times.

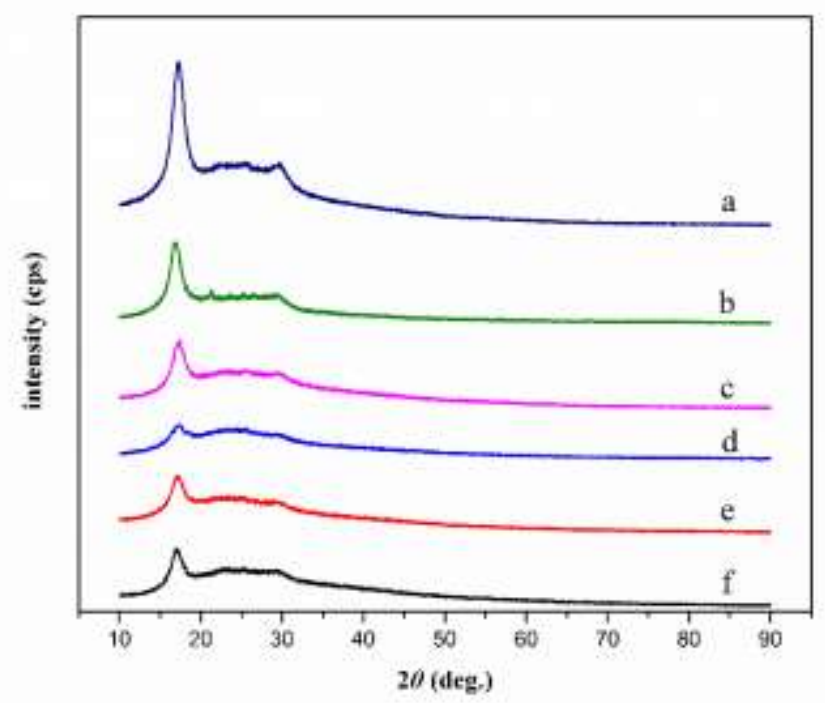

Figure S2 The XRD spectra of (a) PANF, (b) PAN $\mathrm{PF}_{\mathrm{P}}$, (c) PAN $\mathrm{PAPMOD}_{\mathrm{p}-\mathrm{F}}$, (d) $\mathrm{PAN}_{\mathrm{p}-\mathrm{PMOD}} \mathrm{F}-\mathrm{Hg}$, (e) $\mathrm{PAN}_{\mathrm{p}-\mathrm{PMOD}} \mathrm{F}-1$ and (f) $\mathrm{PAN}_{\mathrm{p}-\mathrm{PMOD}} \mathrm{F}-5$

\section{Adsorption Dynamics}

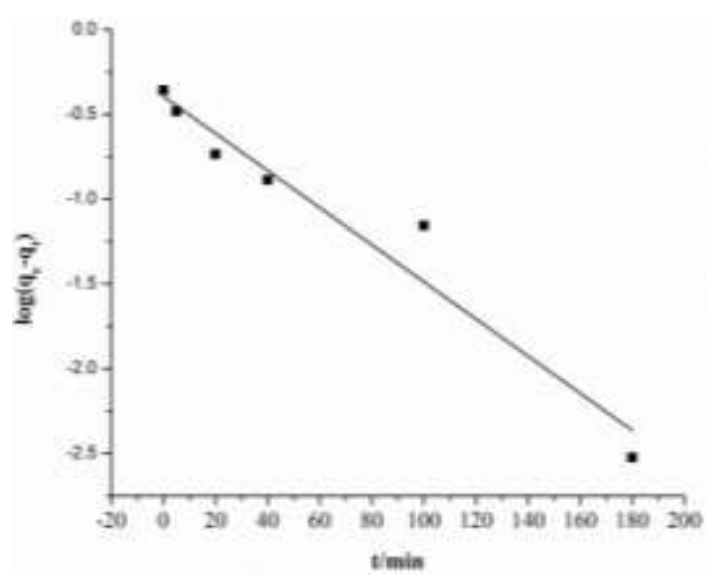

Figure S3 The first-order for $\mathrm{PAN}_{\mathrm{p}-\mathrm{PMOD}} \mathrm{F}$ on $\mathrm{Hg}^{2+}$ 


\section{Adsorption Isotherms}
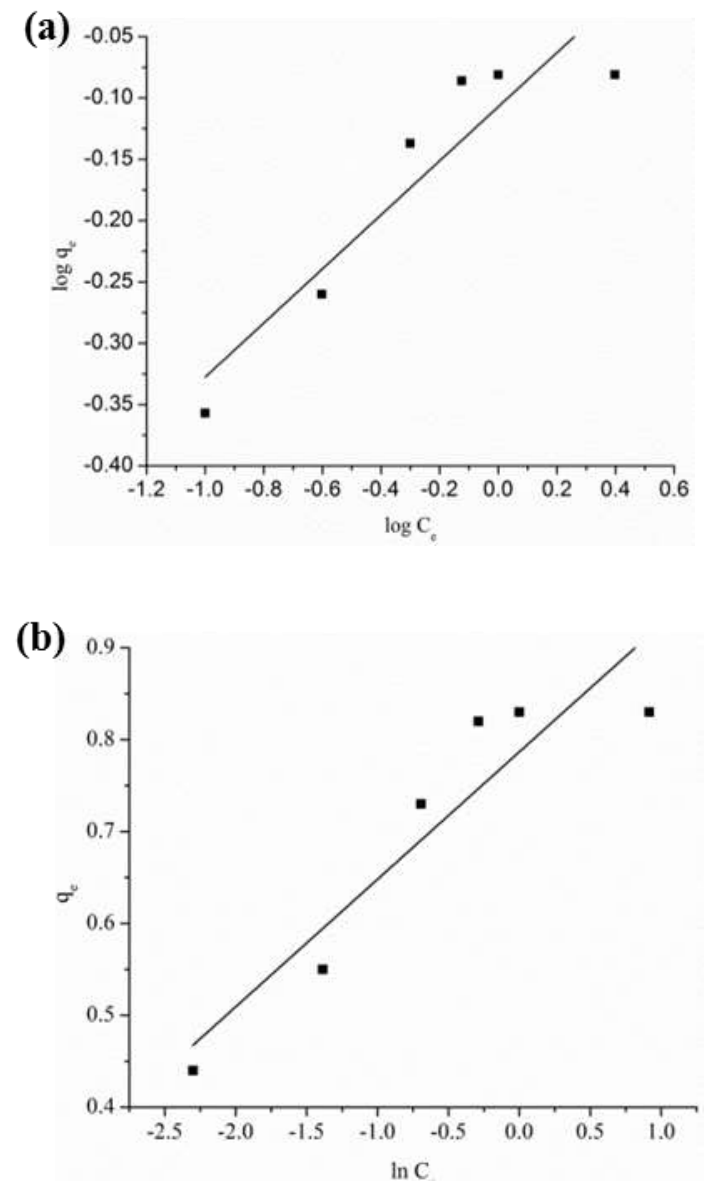

Figure S4 (a) Freundlich adsorption isotherms; (b) Tempkin adsorption isotherms for

$$
\mathrm{PAN}_{\mathrm{p}-\mathrm{PMOD}} \mathrm{F} \text { on } \mathrm{Hg}^{2+}
$$

\section{Comparison of Selective Adsorption Capacities}

Table S3 Comparison of Selective Adsorption Capacities of $\mathrm{PAN}_{\mathrm{p}-\mathrm{PMOD}} \mathrm{F}$ with other Adsorbents Reported in the Literatures for $\mathrm{Hg}^{2+}$

\begin{tabular}{ccccc}
\hline Entry & Adsorbents & $\mathrm{Hg}^{2+} / \mathrm{M}^{\mathrm{n}+}$ & $\begin{array}{c}\text { Ratio of } \\
\text { removal rate }\end{array}$ & References \\
\hline \multirow{3}{*}{1} & $\mathrm{MoS}_{4}$-Ppy & $\mathrm{Hg}^{2+} / \mathrm{Cu}^{2+}$ & 0.4 & \\
& & $\mathrm{Hg}^{2+} / \mathrm{Pb}^{2+}$ & 1.1 & $(8)$ \\
& $\mathrm{Hg}^{2+} / \mathrm{Ag}^{+}$ & 0.8 & \\
& $\mathrm{Hg}^{2+} / \mathrm{Cd}^{2+}$ & 5.6 & \\
2 & \multirow{2}{*}{2} & $\mathrm{Hg}^{2+} / \mathrm{Cu}^{2+}$ & 17.5 & \\
& \multirow{2}{*}{ Polypyrrole-reduced graphene oxide } & $\mathrm{Hg}^{2+} / \mathrm{Pb}^{2+}$ & $\infty$ & $(9)$ \\
& composite (PPy-RGO composite) & $\mathrm{Hg}^{2+} / \mathrm{Cd}^{2+}$ & 15.4 & \\
\hline
\end{tabular}




\begin{tabular}{|c|c|c|c|c|}
\hline 3 & $\begin{array}{l}\text { Bis(2-pyridylmethyl)amino } \\
\text { group-modified polyacrylonitrile } \\
\text { fiber (BPEN-PANF) }\end{array}$ & $\begin{array}{l}\mathrm{Hg}^{2+} / \mathrm{Cu}^{2+} \\
\mathrm{Hg}^{2+} / \mathrm{Pb}^{2+} \\
\mathrm{Hg}^{2+} / \mathrm{Ag}^{+} \\
\mathrm{Hg}^{2+} / \mathrm{Cd}^{2+} \\
\end{array}$ & $\begin{array}{l}1.0 \\
1.0 \\
1.1 \\
1.5 \\
\end{array}$ & (10) \\
\hline 4 & $\begin{array}{l}\text { Graphene oxide and tin(IV) disulfide } \\
\text { composite }\left(\mathrm{GO} @ \mathrm{SnS}_{2}\right)\end{array}$ & $\begin{array}{l}\mathrm{Hg}^{2+} / \mathrm{Cu}^{2+} \\
\mathrm{Hg}^{2+} / \mathrm{Pb}^{2+} \\
\mathrm{Hg}^{2+} / \mathrm{Cd}^{2+}\end{array}$ & $\begin{array}{c}6.1 \\
19.7 \\
66.2 \\
\end{array}$ & (11) \\
\hline 5 & $\begin{array}{c}\text { Thiol-ethylene bridged Periodic } \\
\text { Mesoporous Organosilicas } \\
\text { (nSH-PMO) }\end{array}$ & $\begin{array}{l}\mathrm{Hg}^{2+} / \mathrm{Cu}^{2+} \\
\mathrm{Hg}^{2+} / \mathrm{Pb}^{2+} \\
\mathrm{Hg}^{2+} / \mathrm{Cd}^{2+}\end{array}$ & $\begin{array}{c}7.0 \\
7.9 \\
\infty \\
\end{array}$ & (12) \\
\hline 6 & Chelating resins PS-DEG-3-AP & $\begin{array}{l}\mathrm{Hg}^{2+} / \mathrm{Cu}^{2+} \\
\mathrm{Hg}^{2+} / \mathrm{Pb}^{2+} \\
\mathrm{Hg}^{2+} / \mathrm{Ag}^{+}\end{array}$ & $\begin{array}{c}\infty \\
52.5 \\
8.6\end{array}$ & (13) \\
\hline 7 & PAMMW-Thio fiber & $\begin{array}{l}\mathrm{Hg}^{2+} / \mathrm{Cu}^{2+} \\
\mathrm{Hg}^{2+} / \mathrm{Pb}^{2+}\end{array}$ & $\begin{array}{l}4.8 \\
4.4 \\
\end{array}$ & (14) \\
\hline 8 & $\mathrm{PAN}_{\mathrm{p}-\mathrm{PMOD}} \mathrm{F}$ & $\begin{array}{c}\mathrm{Hg}^{2+} / \mathrm{Cu}^{2+} \\
\mathrm{Hg}^{2+} / \mathrm{Pb}^{2+} \\
\mathrm{Hg}^{2+} / \mathrm{Ag}^{+} \\
\mathrm{Hg}^{2+} / \mathrm{Cd}^{2+}\end{array}$ & $\begin{array}{c}12.4 \\
58.3 \\
2.9 \\
12.0 \\
\end{array}$ & This work \\
\hline
\end{tabular}

Table S3 shows that PAN $\mathrm{N}_{\mathrm{p} \text {-PMOD }} \mathrm{F}$ has greater advantages for selective adsorption of $\mathrm{Hg}^{2+}$ than the $\mathrm{MoS}_{4}-\mathrm{Ppy}, \mathrm{BPEN}-\mathrm{PANF}$ and PAMMW-Thio fiber. ${ }^{8,10,14}$ It is comparable to GO@ $\mathrm{SnS}_{2} .{ }^{11}$ But slightly less than the $\mathrm{nSH}-\mathrm{PMO}$ and the chelating resins PS-DEG-3-AP, ${ }^{12,13}$ In general, the functionalized fiber adsorbent $\mathrm{PAN}_{\mathrm{p}-\mathrm{PMOD}} \mathrm{F}$ has pretty good selectivity for $\mathrm{Hg}^{2+}$ adsorption.

\section{9. ${ }^{1} \mathrm{H}$ NMR Spectra}




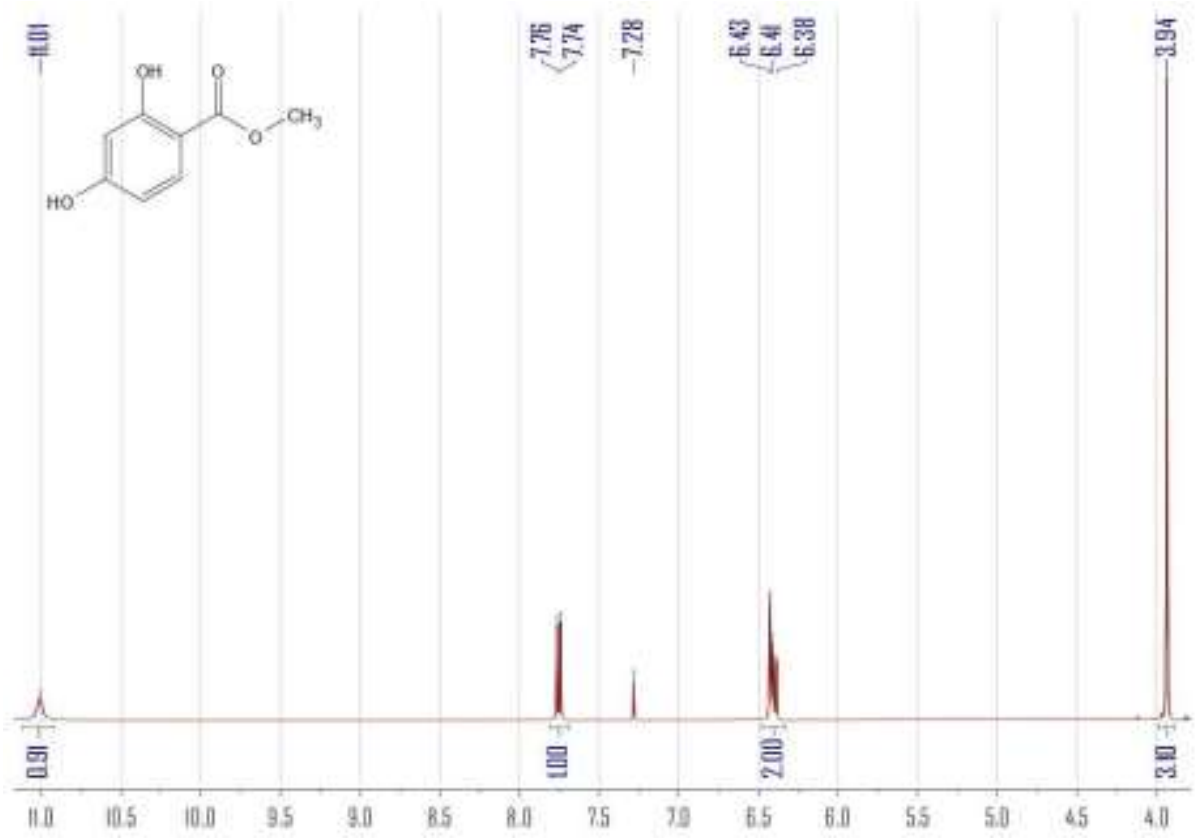

${ }^{1} \mathrm{H}$ NMR spectra of compound $\mathbf{2 b}$ in $\mathrm{CDCl}_{3}$

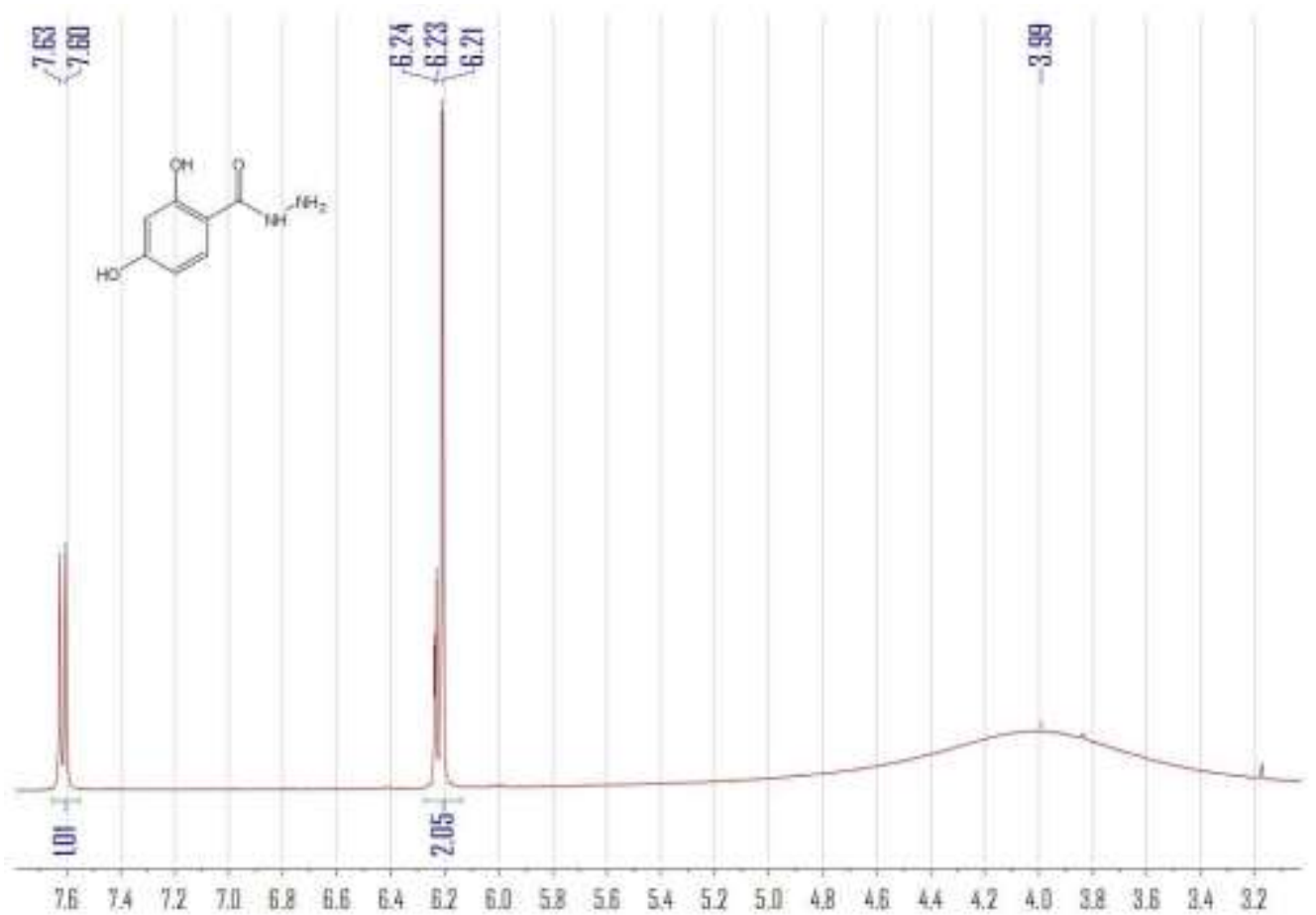

${ }^{1}$ H NMR spectra of compound $3 \mathbf{3 b}$ in DMSO- $\mathrm{d}_{6}$ 

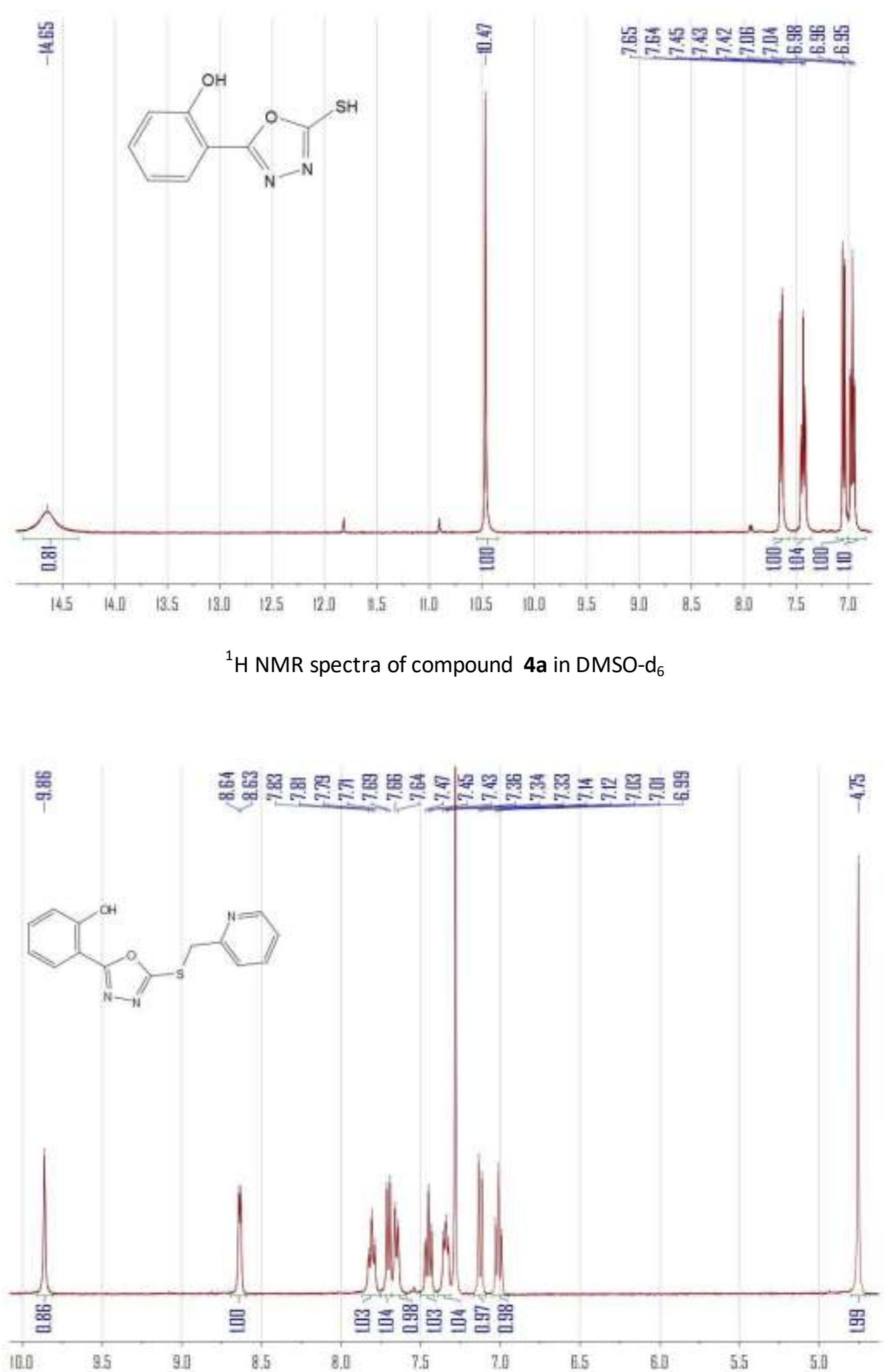

${ }^{1}$ H NMR spectra of compound $\mathbf{5 a}_{\mathbf{2}}$ in DMSO-d $\mathrm{d}_{6}$ 


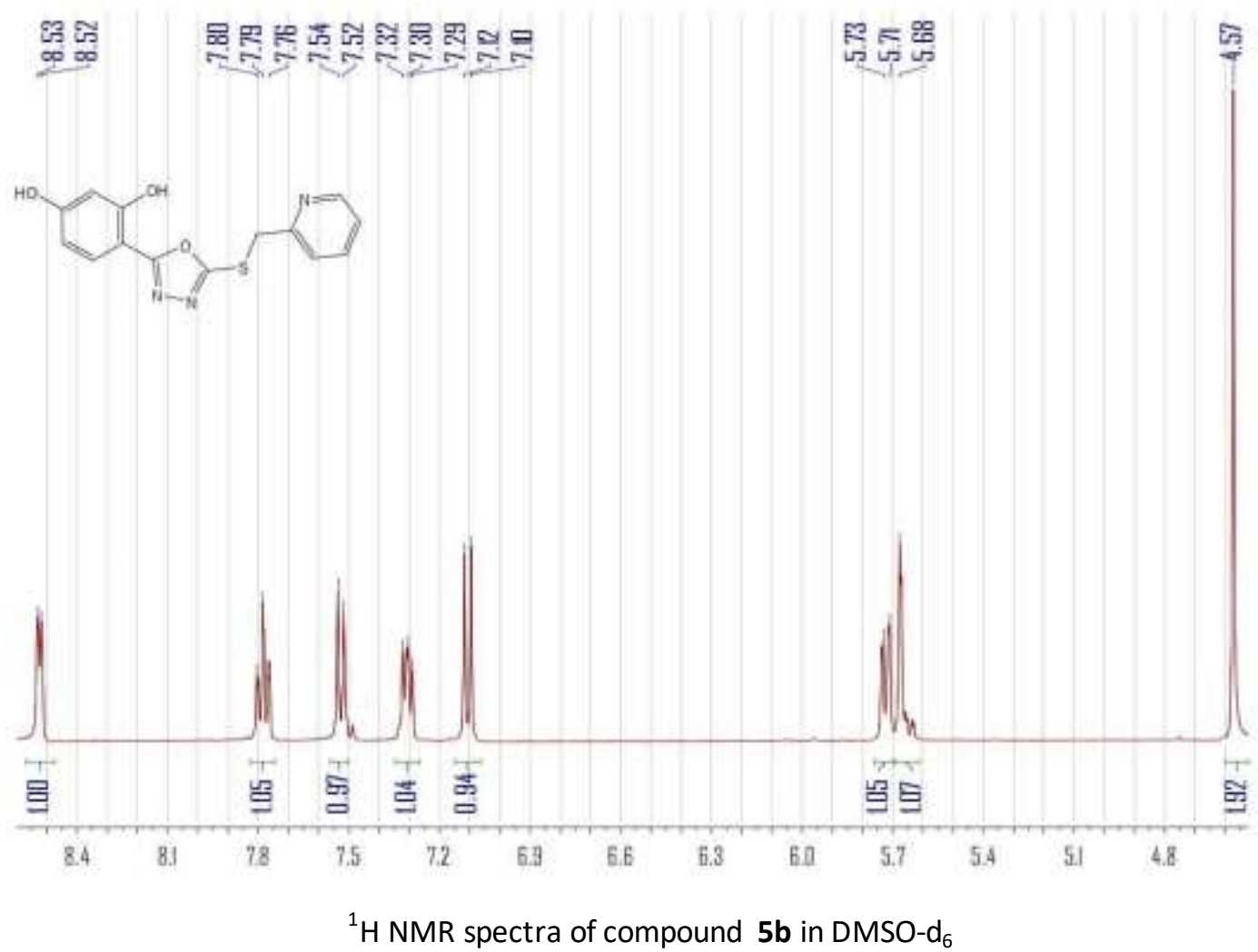

\section{References:}

(1) Tangdenpaisal, K.; Sualek, S.; Ruchirawat, S.; Ploypradith, P. Factors affecting orthogonality in the deprotection of 2,4-di-protected aromatic ethers employing solid-supported acids. Tetrahedron 2009, 65 (22), 4316-4325.

(2) Costes, J. P.; Duhayon, C.; Vendier, L. Synthesis, structural characterization, and magnetic properties of a copper-gadolinium complex derived from a hydroxybenzohydrazide ligand. Inorg. Chem. 2014, 53 (4), 2181-2187.

(3) Arshad, N.; Yunus, U.; Razzque, S.; Khan, M.; Saleem, S.; Mirza, B.; Rashid, N. Electrochemical and spectroscopic investigations of isoniazide and its analogs with ds. DNA at physiological pH: Evaluation of biological activities. Eur. J. Med. Chem. 2012, 47, 452-461.

(4) Aryanasab, F.; Maleki, H.; Saidi, M. R. A novel one-pot synthesis of 2-alkylthio-1,3,4-oxadiazoles in water. J. Iran. Chem. Soc. 2011, 8 (2), 525-530.

(5) Zhang, L.; Li, Z.; Chang, R.; Chen, Y.; Zhang, W. Synthesis and characterization of novel phenolphthalein immobilized halochromic fiber. React. Funct. Polym. 2009, 69 (4), 234-239.

(6) Gao, R.; Xu, G.; Zheng, L.; Xie, Y.; Tao, M.; Zhang, W. A highly selective and sensitive reusable colorimetric sensor for $\mathrm{Ag}^{+}$based on thiadiazole-functionalized polyacrylonitrile fiber. $J$. Mater. Chem. C 2016, 4 (25), 5996-6006.

(7) Liu X, Liu X, Tao M, et al. A highly selective and sensitive recyclable colorimetric $\mathrm{Hg}^{2+}$ sensor based on the porphyrin-functionalized polyacrylonitrile fiber. J. Mater. Chem. A 2015, 3 (25): 13254-13262.

(8) Xie, L.; Yu, Z.; Islam, S.; Shi, K.; Cheng, Y.; Yuan, M.; Zhao, J.; Sun, G.; Li, H.; Ma, S.; 
Kanatzidis, M. Remarkable Acid Stability of Polypyrrole-MoS 4 : A Highly Selective and Efficient Scavenger of Heavy Metals Over a Wide pH Range. Adv. Funct. Mater. 2018, 28 (20).

(9) Chandra, V.; Kim, K. S. Highly selective adsorption of $\mathrm{Hg}^{2+}$ by a polypyrrole-reduced graphene oxide composite. Chem. Commun. (Cambridge, U. K.) 2011, 47 (13), 3942-4.

(10) Xu, G.; Xie, Y.; Cao, J.; Tao, M.; Zhang, W. Highly selective and efficient chelating fiber functionalized by bis(2-pyridylmethyl)amino group for heavy metal ions. Polym. Chem. 2016, 7 (23), 3874-3883.

(11) Rathore, E.; Biswas, K. Selective andppb level removal of $\mathrm{Hg}^{2+}$ from water: synergistic role of graphene oxide and $\mathrm{SnS}_{2}$. J. Mater. Chem. A 2018, 6 (27), 13142-13152.

(12) Esquivel, D.; Ouwehand, J.; Meledina, M.; Turner, S.; Van, T.; Romero, S.; De, C.; Van, D. Thiol-ethylene bridged PMO: A high capacity regenerable mercury adsorbent via intrapore mercury thiolate crystal formation. J. Hazard. Mater. 2017, 339, 368-377.

(13) Ji, C.; Song, S.; Wang, C.; Sun, C.; Qu, R.; Wang, C.; Chen, H. Preparation and adsorption properties of chelating resins containing 3-aminopyridine and hydrophilic spacer arm for $\mathrm{Hg}(\mathrm{II})$. Chem. Eng. J. 2010, 165 (2), 573-580.

(14) Deng, S.; Zhang, G.; Liang, S.; Wang, P. Microwave Assisted Preparation of Thio-Functionalized Polyacrylonitrile Fiber for the Selective and Enhanced Adsorption of Mercury and Cadmium from Water. ACS Sustainable Chem. Eng. 2017, 5 (7), 6054-6063. 